\title{
UKRAINIAN POST-COMMUNIST TRANSFORMATION: CAUSES, CONSEQUENCES AND THREATS
}

\author{
AleKsander KucZabski $^{1}$, TOMAsz MichalsKI ${ }^{2}$ \\ ${ }^{1}$ Department of Socio-Economic Geography and Tourism, Pomeranian University in Słupsk, Poland, \\ and Department of Public Administration and Local Self-Government, Lviv Regional Institute of Public \\ Administration, National Academy of Public Administration Office of the President of Ukraine, Ukraine \\ ${ }^{2}$ Department of Regional Development Geography, Institute of Geography, University of Gdańsk, Poland
}

Manuscript received: February 20, 2014

Revised version: March 25, 2014

KucZABSKi A., Michalski T., 2014. Ukrainian post-communist transformation: Causes, consequences and threats. Quaestiones Geographicae 33(2), Bogucki Wydawnictwo Naukowe, Poznań, pp. 171-180, 4 figs. DOI 10.2478/ quageo-2014-0024, ISSN 0137-477X.

\begin{abstract}
The post-communist transformation of Ukraine differs significantly from that of other countries of Central and Eastern Europe. First of all, Ukraine's transition from totalitarianism to democracy has been long and still remains uncompleted. The process of the democratic transformation in Ukraine is non-linear and can be described by frequent changes in transformation phases. The ultimate result of the country's transformation determines to a considerable extent the geopolitical stability in entire Central and Eastern Europe.
\end{abstract}

KEY WORDS: transformation, democracy, Ukraine, Central and Eastern Europe, Russian Federation

Aleksander Kuczabski, Department of Socio-Economic Geography and Tourism, Pomeranian University in Stupsk, ul. Partyzantów 27, 76-200 Stupsk, Poland; e-mail: kuczabski@mailplus.pl

\section{Introduction}

The development of Ukraine as an independent state is connected with complicated transformation processes typical of most post-communist states in Central and Eastern Europe. However, the situation of Ukraine after the collapse of the communist system turned out to be more challenging than that of its neighbours. Generally speaking, Ukraine has been going through three phases of social transformation at once. First, the decolonisation of governance is taking place. The system of government must be reorganised in accordance with national and not imperial interests. Second, the decentralisation of government facilitates an evolution from the totalitarian to a democratic regime. Third, the denationalisation of the economy, which is also under way, results in the rejection of a directive type of administration in favour of regulation and stimulation (Kučabs'kij 2010).

According to Mach (1998), there are four types of East-European post-communist transformation:

1. Substitution. This type implies that the essence of institutional changes in post-communist European countries is based on modernisation. This means a substitution of centralised and rigidly managed economy, its political superstructure and the social consequences involved with a modern West-European capitalist model. As a necessary element, this approach assumes a rapid and ultimate abandonment of the old communist model. 
2. Transplantation, which can exist in two versions. One presumes that in the process of East-European transformation certain elements of the old order remain unchanged. The other allows the continuing existence of the old institutional structure in which only certain elements of the new system are implemented.

3. Recombination, which implies that neither institutions nor individuals are able to perform rapid radical changes. For this reason the transformation of post-communist European countries means modification and re-configuration of those individual elements that existed in the economy and society when the transformation was launched.

4. Retrogression, which presumes a justified threat that the process of transformation can actually mean a return to organisational and mental forms of the pre-transformation times and thus steer the transformation itself towards collectivism and authoritarianism, and generate fear of the future.

The multidirectional nature of transformation processes, as well as their overlapping, undermined the stability of public institutions in Ukraine. This, in turn, led to a prolonged social and economic crisis. As a result, Ukraine failed to achieve essential correspondence between new social values and priorities and public administration methods that often remain totalitarian. As Lesečko and Čemeris claimed (2001: 95), "Ukraine has found itself on the verge of a peripheral zone, and it is becoming more and more problematic for it to rise in the global hierarchy". Thus, to use Mach's terminology, the post-communist transformation processes in Ukraine that were initially planned as transplantation and later entered the recombination phase have recently acquired explicit features of retrogression. At the same time, it must be noted that the process of curtailing democratic changes is non-linear. Massive public and political protests of 2004, known as the Orange Revolution, for a short time disrupted this negative tendency. However, due to a number of reasons and first of all a destructive impact of the global economic crisis on the Ukrainian economy, pro-democratic political forces lost the political support of the majority of voters and transformed into an oppo- sition. The signing of the European Union Association Agreement planned for 2013 was viewed as another chance to renew democratic changes in Ukraine. A unilateral decision of the Ukrainian government to postpone the signing of this Agreement and a sharp change in the country's geopolitical course, now targeted at building closer relations with the Russian Federation, led to new large-scale protests and attempts of the regime in power to suppress them by force.

At the moment when this paper is submitted for publication (February 2014), it is not clear yet if the recent public unrest will be able to push Ukrainian society towards transplantation or if the country will keep drifting towards retrogression. At the same time, it is obvious that in Ukraine the process of recombination in its current form has exhausted itself.

\section{Initial situation, causes and consequences of transformation problems}

Before 1991 the disappearance of the Soviet Union as a state did not seem to be a realistic geopolitical prospect. At that time, the separation of Lithuania, Latvia and Estonia posed the greatest threat to the USSR. However, it was the political crisis of 1991 and the failure of the military coup in August 1991 that discredited the Kremlin's political power and gave an impulse to the collapse of the country. In 1991 the majority of former USSR dependencies acquired features of formal and later informal independence as individual states. This process was finalised in December 1991 when Ukraine became an independent entity of international politics that inherited from the USSR the old system of public (and territorial) administration (Fig. 1).

At the time when Ukraine gained independence in 1991, it was characterised by a number of specific features that affected its further transformation.

\section{Internal disintegration}

Although Ukraine consisted of territories inhabited mainly by Ukrainians, its regions had 


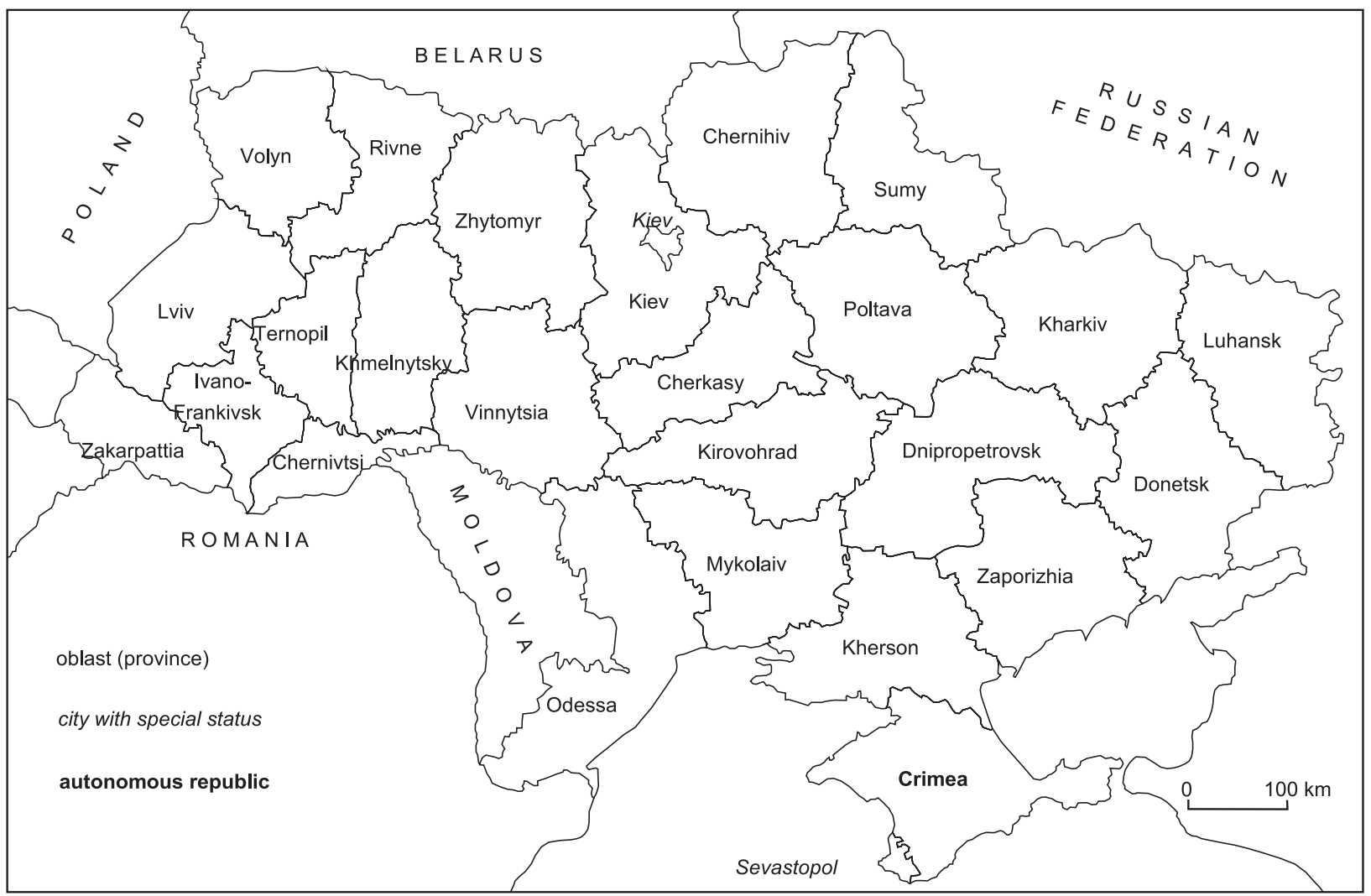

Fig. 1. Administrative division of Ukraine Source: Kučabs’kij (2010: 152)

significant political, social and economic features. Sometimes those features were clearly destructive. This situation is explained by the history of Ukraine's border-setting in 1920-1954 that was determined by the geopolitical will of the Kremlin's political leaders. The emergence of Ukraine in 1991 was a geopolitical compromise rather than a result of the political will for independence expressed by the majority of its population. According to the Soviet referendum about the preservation of the Soviet Union that took place on 17 March 1991, only 20\% of voters in the Ukrainian Soviet Socialist Republic (mainly in Western Ukraine) had the courage to vote against it. However, the outcome of the Ukrainian referendum of 1 December 1991 was the opposite: 90.3\% voted for the independence of Ukraine and against its being part of the Soviet Union. That proved how undetermined the citizens of the future Ukrainian state were in their vision of the country's political future and how big the danger of manipulation of the Ukrainian voters was.

At the same time, the Ukrainian referendum of December 1991 was recorded in history as the first democratic plebiscite held in the country in seventy years. It pointed to obvious territorial differences as regards the imagined political future of the country (Fig. 2).

However, as opposed to Belarus that irreversibly entered the retrogression phase in 1993, Ukraine long strived for democratic transformations by transplantation or recombination. Traditionally, most voters in today's Ukraine politically support democratisation and European integration while residents of a specific, geographically compact part of the country are inclined to preserve the authoritative model and a pro-Russian policy.

The main civilisational split of modern Ukraine divides it into two major parts: Central Western and South-Eastern ones. A specific feature of Ukraine is lack of a geographical borderline between different parts of the country. Typically, they are separated by a broad transition zone, and in each of the two regions we can observe considerable enclaves and intrusions with characteristic features of the other one. In order to visualise these peculiarities, one might compare 


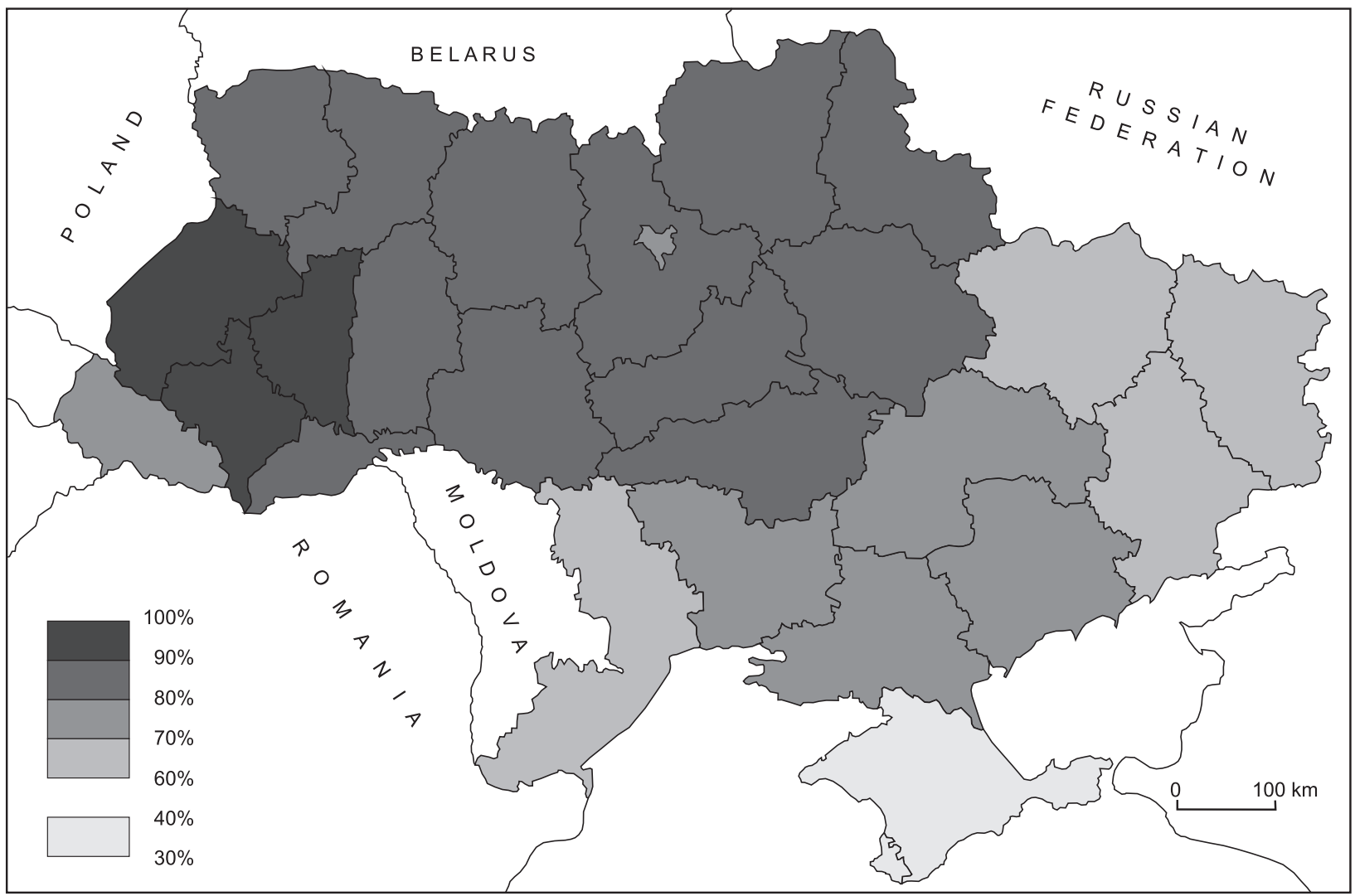

Fig. 2. Percentage of voters who supported independence during the referendum on 1 December 1991 (out of the total number of voters)

Source: http://www.archives.gov.ua/Sections/15r-V_Ref/index.php?11 (modified)

the territorial breakdown of Victor Yushchenko's support during the presidential election of 2004 (Fig. 3) and an almost diametrically opposite distribution of support for Victor Yanukovych during the presidential election of 2010 (Fig. 4). For the first time, the referendum of 1 December 1991 demonstrated this division in an explicit way. Later it was only confirmed by the results of all political elections in the country.

Dejč (2005: 21) makes a conclusion about too high a level of political differentiation in Ukraine and sees a crucial difference of systemic elements in the "mentality as a way of these elements to create stable systems". Kordun (2006: 167) claims that internal civilisational differences in Ukraine can be explained, among others, by "different visions of the same historical events and leaders, a selection of different models of behaviour, and even by essentially different assessment of the very fact of Ukrainian independence in different regions of the country". Majboroda (2006: 121) believes that "it is not possible to downplay" those regional differences.
However, internal differences in Ukraine are illustrated not only by the above dual split. For example, democratically-minded Central Western Ukraine consists of mentally and culturally heterogeneous regions. The westernmost regions that were forced to join the USSR (and Soviet Ukraine) as a result of World War II remain most pro-Western and pro-democratic. This refers in particular to Galicia, which used to be part of the Habsburg monarchy and later interwar Poland, Volyn, a former part of the Romanov Empire and Poland, Zakarpattia (Transcarpathia), which after the collapse of the Habsburg monarchy became part of Czechoslovakia and then Hungary, and finally Bukovyna, which used to be in the Habsburg monarchy and later in Romania.

The South-Eastern part of Ukraine that was most severely affected by the destructive power of the communist administration remains more homogeneous. The main circumstances that shaped the current image of that region include Stalinist collectivisation and industrialisation. Collectivisation and a few periods of famine ru- 


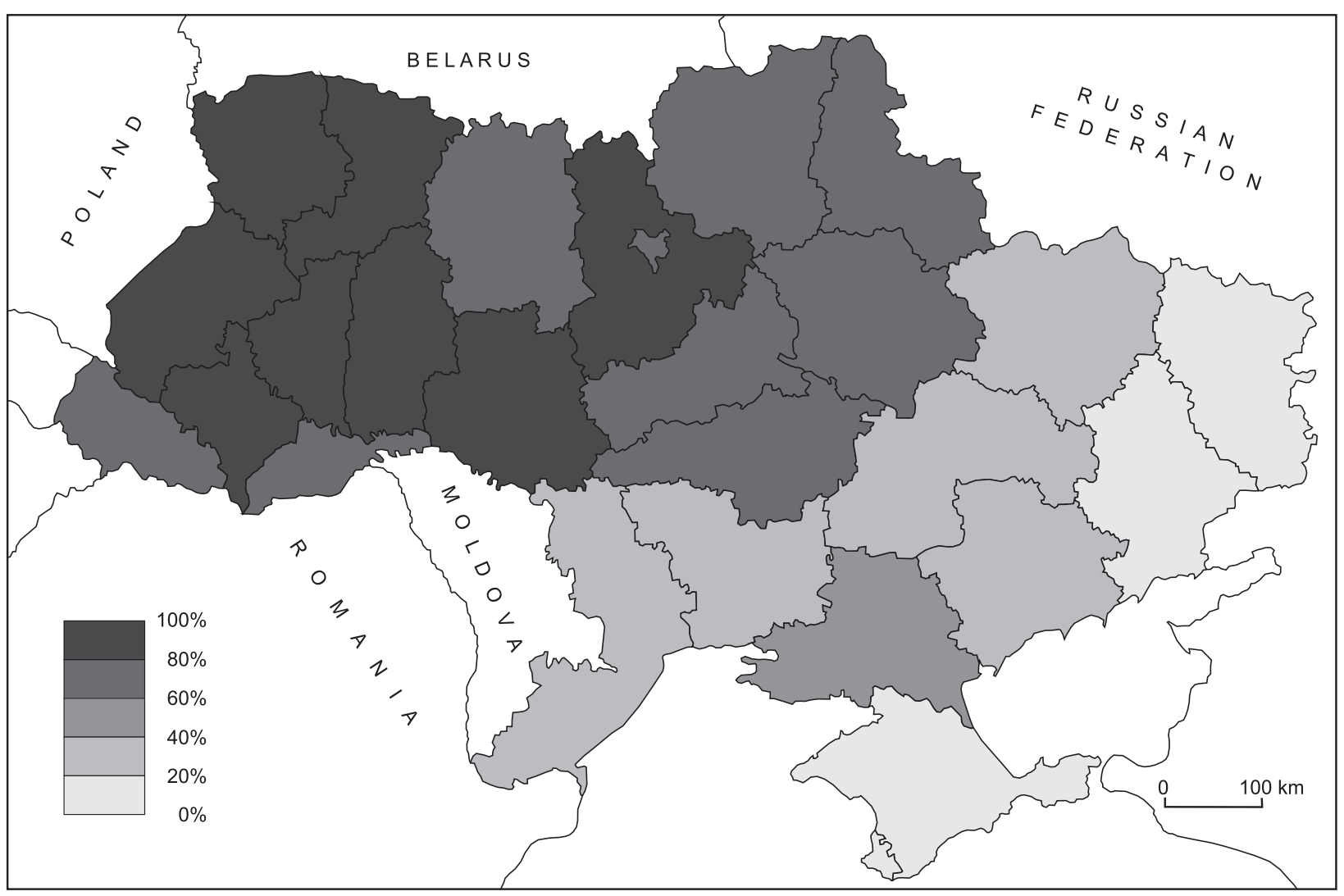

Fig. 3. Percentage of votes in Yushchenko's support at the 2005 presidential election Source: http://www.cvk.gov.ua/pls/vp2004/wp0011 (modified)

ined the traditional Ukrainian way of country life and contributed to a social and economic degradation of the agricultural periphery. On the other hand, industrialisation contributed to the development and dynamic growth of major industrial centres with an ethnically mixed (although mainly Ukrainian-Russian) population recruited from different parts of the USSR and emotionally not involved in efforts to establish a Ukrainian state.

However, in this region we can also identify individual specific parts. First of all, there is Crimea and Sevastopol with a dominant ethnic Russian population and an influential number of Crimean Tatars. The Donbas area deserves special attention. It is a typical and obvious product of Stalin's industrialisation since it specialises in all stages of coal-mining and coal-processing. Although statistically this region is represented as a Russian-Ukrainian mixture, in fact it is exclusively Russian-speaking and considerably uprooted. The ethnically diverse southern Bessarabia is another Ukrainian region that differs from the rest of the country. This area was finally incorporated into the USSR in 1944, and during the collectiv- isation and famine of 1946-1947 suffered severe social, economic, and demographic destruction.

It is obvious that in addition to a geographical split there are other differences. First, there is an ethnic and a linguistic diversity. According to Nadolišnij (1999: 147-148), the issue of the ethnic composition of the population is particularly important when the state is being created or developed. At present, the territory of Ukraine includes a number of ethnic minority regions that by means of political mechanisms actively engage in civilisational opposition.

As of 1991, three powerful groups lived in Ukraine: Ukrainian-speaking, Russian-speaking and bilingual citizens. Over the subsequent years no radical change took place in the linguistic landscape of the country.

Another tendency is the accumulation of controversies and distrust of the capital city that in opposition to its poor and deteriorated periphery is becoming the place of a considerable concentration of resources. Lupacij (2006: 152) described the relationship between the capital city and the regions of Ukraine as "internal colonialism". As 


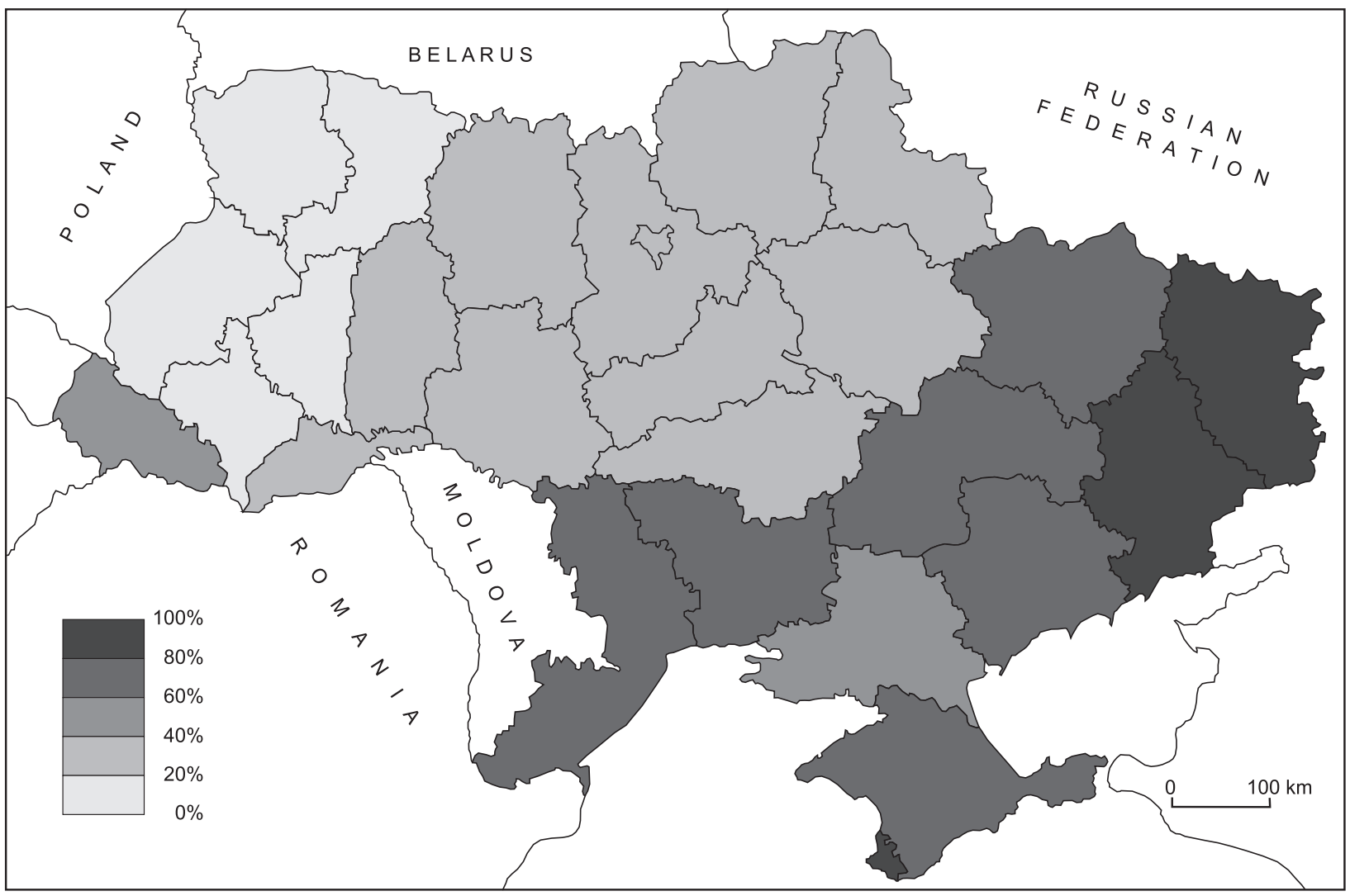

Fig. 4. Percentage of votes in Yanukovych's support at the 2010 presidential election Source: http://www.cvk.gov.ua/pls/vp2010/WP0011 (modified)

a result, Kiev no longer performs transitional functions of a capital city and is turning into a metropolis.

Galicia (with its characteristic anti-communist and somewhat nationalistic political preferences) and the pro-Russian and pro-communist Crimea and Donbas remain controversial regions for an average Ukrainian.

\section{Economic handicap}

The economic system of Ukraine was formed as an integral part of the so-called "single economic complex of the USSR" long before 1991. The latter originated from Stalin's industrialisation of the early 1930s. Hence, the military-industrial complex with the manufacturing of arms, weapons and related products took the central place in it. This peculiarity accounted for the creation of an economic mechanism based on directive planning and not market relations. Prior to 1991, the main objective of the Ukrainian economy was to ensure military equilibrium between the Warsaw Treaty members and the NATO members. The achievement of this objective presumed close cooperation between military companies in the entire Soviet Union and its satellite countries.

After the collapse of the Soviet Union, conversion came to the foreground. It meant a reorganisation of the military production into mass-consumption goods manufacturing. However, that process was not successful. The disruption of cooperation between military companies that found themselves in different countries after 1991, as well as their inefficiency, uncompetitiveness and inability to adjust to market conditions led to their massive bankruptcy and only deepened the economic crisis.

The distinctly military specialisation of the Ukrainian economy at the moment when the USSR collapsed largely distorted real statistical data. Weapons and military supplies that were included in statistics made a significant part of the GNP. However, they not only failed to show realistically the level of material welfare of the population, but with time became a burden for the budget as their utilisation required considerable expenses. According to official statistics, in 
1990 the GNP in Ukraine was higher than in Poland. However, even then an average Ukrainian was poorer than his/her Western neighbour.

The initial economic handicap of Ukraine was also connected with considerable obsoleteness of its manufacturing facilities. The USSR could not afford any major investments in their modernisation because it had to catch up in the arms race with the USA after World War II. When Ukraine gained independence in 1991, main technologies of its companies were obsolete and required significant investments from the state budget.

Efforts aimed to modernise the economy by privatisation and the introduction of market mechanisms did not have sufficient political support and did not lead to essential changes. In a competitive environment, a number of industrial giants went bankrupt while others, as a result of unfair and corrupted privatisation, passed into the ownership of the so-called nomenclature, i.e. representatives of the post-communist political elite. Lupacij (2006: 152) claims that at the moment of "great privatisation" Ukraine moved from a bureaucratic to a clan-based corporative model of re-integration.

Metallurgical and chemical companies helped Ukraine to find a place on the international market. The affordable cost of their products resulted from a relatively cheap Russian energy resources and extremely low-paid labour. The oligarchic economic model that emerged in Ukraine restrained a revival of the country's economy. Oligarchs who managed to get control over the main part of production assets in a short time, actively influenced and determined government policies. In particular, they restricted the development of small and medium-sized businesses and suppressed the emergence of the middle class.

\section{Social and political inertness}

Kul'čic' kij (2003: 41) believes that the strategic vector of transformation of the economic system is connected with dominant social values. As of 1991, the majority of the population in Ukraine could be described as Soviet people, i.e. a specific form of ethnic and cultural community that primarily identified with the USSR and not the Ukrainian Socialist Republic where they actually lived. According to surveys conducted by the
Institute of Sociology of the Ukrainian National Academy of Sciences, even in 2005 eight percent of Ukrainians still considered themselves citizens of the former Soviet Union (Panina 2005: 60).

As an overall reflection of the homo sovieticus ${ }^{1}$ psychological type, Soviet people were characterised by specific psycho-physical features, first of all by paternalism. In 1991, the majority of Ukrainians were not only unprepared for market reforms but also avoided active engagement in social and political life. In this context Dolišnìj (2006: 115) remarked that "successful reforms of the country's economy in general and the development of an efficient administrative system at the national and regional levels is impossible without the development of a civil society."

The oligarchy which grew out of the Communist party nomenclature and took control over the economy managed to expand its influence also to political institutions. Lack of efficient public control and real self-government as well as the weakness of the democracy-oriented political opposition facilitated systematic usurpation of political power by oligarchs. In the atmosphere of almost non-existent political culture and responsibility, corrupt bureaucratic structures created to imitate the mechanisms of democratic public administration substituted for genuinely democratic institutions.

In this context it is appropriate to present peculiarities of the administrative reform in Ukraine as analysed by Goncâž and Gnidûk (2002). The authors believe that Ukrainian society "plays the role of an anonymous background or a passive witness to, but not a participant of, events. Changes are a game in which only small groups of politicians from the highest circles of government take part, whereas citizens and specific social groups do not perform any role as far as the suggestion or implementation of changes are concerned" (Goncâž, Gnidûk 2002: 10). On the other hand, as Lesečko and Čemeris remark (2001: 98), "the administrative elite turned out to be unprepared for the implementation of transformations or unwilling to get engaged in them".

It is obvious that under the circumstances any real reforms that would restrict the power of the

1 The term was introduced by the Russian philosopher Zinoviev (1986). 
oligarchy and bureaucrats are impossible. Instead, an information fuss is being created about the necessity to carry out essential reforms in all walks of social life. As long ago as in 2002, it was pointed out that the nature of the post-Soviet social process is spontaneous and unmanaged, and is characterised by "a non-systematic reaction to the current situation and the influence of shortterm selfish corporate interests" (Mel'nik 2002: 88).

Analysts tend to believe that as a result of the considerable social and political inertness inherited from the Soviet totalitarian past, "Ukraine created a clumsy and inefficient system of public administration unable to plan reforms and implement them, thus it did not respond to the needs and expectations of society at its current stage of development" (Timoŝuk 2002: 7).

In addition to the above-mentioned internal circumstances, the proximity of the Russian Federation has played an extremely important part in the course of transformations in Ukraine. In the past, the territory of Ukraine made up a considerable part of the social and economic resources of the Russian Empire and later the Soviet Union. Besides, in the Russian version of history, the territory of present-day Ukraine is seen as the cradle of Russian statehood. This explains the position of Russian pro-imperialistic political circles that see the return of Ukraine under the Kremlin's political control as a key element for the renewal of the geopolitical power of Russia.

Although formally the Russian Federation is a protector of the state integrity of Ukraine, since 1991 Ukraine has experienced a continuous and systematic interference of the Russian Federation with its affairs. Dependence on energy resources is the main mechanism of this influence. Recently, the range of Russian pressure on Ukraine was supplemented by financial dependence and economic blackmail.

\section{Conclusions: threats to and possible scenarios of a further transformation}

The specific features of Ukraine's situation described above determined the main tendencies of its development in the early 1990s:
- Emigration. The hard social and economic situation in Ukraine that has continued for more than twenty years, brought into being two main types of emigration: intellectual and labour-oriented. In Ukraine the so-called brain drain took place on a huge scale compared with other countries of Central and Eastern Europe, and irreversibly damaged the social and economic future of the country. Labour emigration posed a similar danger and was even more massive. It made many economically active but unemployed people leave the country in search of jobs. The systematic curtailing of democratic liberties may give an impulse to another wave of emigration in the nearest future - political emigration. The most serious consequences of mass emigration from Ukraine include increasing depopulation as a result of the emigration of individuals of reproductive age, as well as criminalisation and social degradation. The latter is caused by the spread of the incomplete family model and lack of systematic parental care of children and youth.

- Power usurpation. The lack of democratic and local self-government traditions as well as political inertness of the majority of the population have created favourable conditions for political power usurpation. The oligarchy that fully controls political power in Ukraine at the moment has created a closed system of public administration and made it inaccessible for the few disloyal public and political institutions. Institutions of direct democracy, formally guaranteed by the Constitution, do not actually function. Methods of interference with the expression of the political will of Ukrainians are widely used and range from bribery of voters to electoral fraud.

- Corruption. Power usurpation which excludes community control over government institutions has created extremely favourable conditions for large-scale corruption. Under such circumstances, the bureaucratic system is fully dependent on those currently in power, cannot be controlled by common citizens, and remains immune to punishment. This favours a corruptive environment for almost the entire population of the country. For example, according to a survey conducted by the socio- 
logical service of Razumkov's Centre between 30 September and 8 October 2013, 44.9\% of respondents believe that "the entire government is corrupt," $37.4 \%$ believe that corruption in this sphere is rather widespread, and only $1.1 \%$ are convinced that there is no corruption (Centr Razumkova).

- Separatism. The continuous internal disintegration accounts for a permanent threat that certain regions and territories may secede from Ukraine. As Konotopcev claims (1999: 34), in Ukraine "individual regions of the country are still biased towards other countries: Russia, Poland, Hungary, etc. Under such circumstances federalisation and decentralisation create a favourable environment for separatism as the situation in Crimea unambiguously shows". Separatist tendencies in Ukraine can be explicitly connected to an increase of tension in relations with the Russian Federation. At the same time, there are also attempts to encourage separatism in other ethnically and mentally specific areas of the country, such as Zakarpattia (Transcarpathia), the Romanian part of Bukovyna, and even Galicia.

Since 1991, Ukraine has maintained a fragile geopolitical equilibrium in Eurasia. At present, it plays the role of a buffer state between the European Union as a representative of Western democratic values and the authoritarian Russian Federation, which does not conceal its expansionist and revanchist ambitions in relation to its formerly dependent territories, including Ukraine.

Besides, the destabilisation of the situation in Ukraine might threaten the entire region of Central and Eastern Europe. We can identify the following possible scenarios for the development of the situation in Ukraine:

1. Inert, which presumes the preservation of the status quo with Ukraine as a buffer state between the European Union and the Russian Federation.

2. Optimal or Central European, which implies gradual integration of Ukraine into the EU structures. The political crisis in Ukraine in the late 2013 / early 2014 demonstrated that supporters of the pro-European course are both numerous and publicly and politically active. A profound political crisis complicated by a mounting economic collapse can lead to a change of the governing political elite, even if this process contradicts the expectations of the Russian Federation and involves large-scale blackmail (from commercial to military).

3. Destructive or Belarusian, which is connected with intensive subordination of Ukraine to the Russian Federation. It will be possible if the European Union opts out of the Ukrainian problem and Russian geopolitical expansion continues. The implementation of this scenario would include an increase in the financial and economic dependence of Ukraine on the Kremlin. It will lead to a further departure from democratic mechanisms of administration in favour of the authoritative model of Belarusian type.

4. Catastrophic or Balkan, which may lead to a territorial disintegration of the country into what we may tentatively call a pro-European and a pro-Russian part.

Each of the scenarios is fraud with significant dangers and threats, not only to Ukraine and the neighbouring countries, but also to all countries of the European Union.

In a short-term perspective of a year or two, we can expect the deepening of the social and economic crisis in Ukraine. It will be accompanied by an increased pressure of the Russian Federation on political processes in the country and will boost internal conflicts in it. Energy resources will remain the key to economic and probably also political dependence of Ukraine upon the Russian Federation. Besides, other weak aspects of modern Ukraine will be used as a tool for its subordination.

In a mid-term perspective of the nearest ten years or so, we can expect serious changes on the global market of energy resources that will weaken the geopolitical role of the Russian Federation. Economic threats causing a decrease in the cost of energy resources on the world market are comparable to the processes that took place during the final years of the USSR. Without exaggeration they can give rise to a large-scale social and economic crisis in Russia that will lead to a change of its governing political elite.

In a long-term perspective, both Ukraine and the Russian Federation will complete the process of transformation from totalitarianism to 
democracy that started in the late Soviet period. Unfortunately, it is hard to predict what the cost of these transformations will be and whether the existing states will keep their current borders. These changes will be a precondition for the inclusion of both countries into the orbit of the European geopolitical body. The European integration of Ukraine and Russia will take place almost simultaneously and will close the transformation of entire Central and Eastern Europe from totalitarianism to democracy.

Taking into consideration the specific situation of modern Ukraine, it is possible to state that, compared with other countries of Central and Eastern Europe, the process of its democratic transformation is characterised by the following three essential aspects: relatively long duration, simultaneity of all the transformation phases (as described in Mach's classification), and their frequent non-linear transitions.

\section{References}

Central'na wiborča komìsiâ (Central Election Commission). Online: http:// www.cvk.gov.ua (accessed 31 January 2014).

Centr Razumkova (Razumkov Centre). Online: http:// www.cvk.gov.ua http:// www.uceps.org/ ukr/poll. php?poll_id=903 (accessed 31 January 2014)

Dejč W.B., 2005. Regional'naâ celostnost' Ukrainskogo gosudarstwa na sowremennom ètape razwitiâ (Regional integrity of the Ukrainian state at current stage of its development). Menedžer. Wistnik Doniec'koï Deržawnoi Akademï̈ Uprawlìnnâ 4: 17-23.

Dolišnìj M.I., 2006. Regional'na politika na rubežì XX - XXI stolit': nowi prioroteti (Regional policy in the late 20th-early 21st centuries: New priorities). Naukowa dumka, Kiïw.

Goncâž Â., Gnidûk N., 2002. Adminisstratiwna reforma: nezdìjsnenì mrï ta wtračenì možliwostì. Âk snajti konstruktiwnij šlâh dlâ realizaciì osnownih komponentìw administratiwnoi reformi? (Administrative reform: Unfulfilled dreams and lost opportunities. How do we find a constructive way to implement essential components of the administrative reform?). Mìlenìum, Kiïw.

Kordun O., 2006. Analìz pitan' ŝčodo wrahuwannâ radâns'koï spadŝini w socìogumanìtarnìj polìticì Ukraïni (Analysis of Soviet legacy issues in social policy and policy in humanities in Ukraine) In: Tiŝčenko Û. (ed.), Regional'na politika Ukraïni: formuwannâ sociogumanitarnih prìoritetì w rozwitku. Ukraïns' kij nezaležnij centr polìtičnih doslìdžen' Kiïw: 161-180.

Konotopcev O.S., 1999. Ewolûcîâ admìnìstratiwno-teritorìal'nogo ustoû Naddnìprâns 'koï Ukraïni (Evolution of the administrative and territorial organisation of the Dneper Region in Ukraine). Aktualni Problemi Deržawnogo Uprawlinnâ 1: 24-34.

Kučabs'kij O., 2010. Admìnistratiwno-teritorìal'na organizaciâ Ukraïni: teoriâ, metodologîa, mehanizmi stanowleniâ (Administrative and territorial organisation of Ukraine: Theory, methodology, and mechanisms of development). Widawnictwo LRIDU NADU, L'vìv.

Kul'čic'kij B., 2003. Tipologìzaciâ ekonomičnih system u kontekstì gnoseologii suspïl'nih transformacìj (Typology of economic systems in the context of social transformation gnoseology). Regional 'na Ekonomika 2: 37-41.

Lesečko M.D., Čemeris A.O., 2001. Admìnìstratiwna reforma: doswìd Pol'ščì ta ukraïns'kì realiii (Administrative reform: Polish experience and Ukrainian realities). Aktualnì Problemi deržawnogo uprawlìnnâ ОФ УАДУ 4: 91-105.

Lupacìj W., 2006. Ukraïna w pošukah nowoï modelì reìntegraciì (Ukraine in search of a new model of reintegration). In: Tiščenko Û. (ed.), Regional'na politika Ukraïni: formuwannâ sociogumaitranih prìoritetìw rozwitku. Ukraïns'kij nezaležnij centr polìtičnih doslìdžen', Kiïw: 147-161.

Mach B.W., 1998. Transformacja ustrojowa a mentalne dziedzictwo socjalizmu (Systemic transformation and the mental legacy of socialism). Instytut Studiów Politycznych PAN, Warszawa.

Majboroda O., 2006. Zagal'nonacional'nì ì regìonal'nì ìnteresi w sučasnij Ukraïnì (National and regional interests in modern Ukraine). In: Tiŝčenko Û. (ed.), Regional'na politija Ukrä̈ni: formuwannâ sociogumaìtranih prìoritetìw rozwitku. Ukraïns'kij nezaležnij centr polìtičnih doslìdžen', Kiïw: 121-147.

Mel'nik M.I. (ed.), 2002. Rozwitok lûds'kogo pesursu admìnistratiwnoï reformi w Ukraïnì: stan ì perspektiwi (Development of human resources of the administrative reform in Ukraine: Condition and perspectives). Nora-prìnt, Kiïw.

Nadolišnìj P.I., 1999. Rozbudowa nowoï sistemi wrâduwannâ w Ukraïnì: etnonacional'nij aspekt (Teoretioko-metodologičnij analiz) (Development of a new system of administration in Ukraine: Ethnic and national aspects (theoretical and methodological analysis)). Widawnictwo UADU „StroPrint", Odesa.

Panina N., 2005. Sociologičesjij monolit: Ukrainskoe obŝestwo 1994-2005: God pereloma (Sociological monitoring: Ukrainian society in 1994-2005: the year of transition). ISNANUkraïni, Kiïw.

Timoŝčuk W.P., 2002. Admìnistratìwna reforma - ìstoriâ, očikuwannâ ta perspektiwi (Administrative reform - history, expectations and perspectives). Fakt, Kiïw.

Widomist' pro rezul'tati Wseukraïns 'kogo referendumu, 1 grudnâ $1991 r$. (Data about the results of the Ukrainian national referendum of December 1, 1991), CDAWOW Ukraïni (Central Government Archives). Online: http:// www. archives.gov.ua/ Sections/ 15r-V_Ref/ index.php?11 (accessed 31 January 2014).

Zinoviev A., 1986. Homo Sovieticus. Atlantic Monthly Press, Boston. 